\title{
Medicinal plant essential oils associated with biofilm to protect papaya fruits
}

\author{
Pedro Raymundo Argüelles OSORIO ${ }^{1}$, Priscila Fonseca COSTA ${ }^{1}$, Mateus Sunti DALCIN ${ }^{1}$, \\ Dalmarcia de Souza Carlos MOURÃO ${ }^{1}$, Raimundo Wagner de Souza AGUIAR ${ }^{1}$, \\ Gabriella Rayssa Antunes da Silva OLIVEIRA ${ }^{1}$, David Ingsson Oliveira Andrade de FARIAS ${ }^{1}$, \\ Felipe Rocha DIAS ${ }^{1}$, Gil Rodrigues dos SANTOS ${ }^{1 *}$ (iD
}

\begin{abstract}
The objective of this work was to associate the use of biofilms to Lippia sidoides (Lippia) and Morinda citrifolia (Noni) essential oils and their respective major constituents in post-harvest quality components. The evaluations in this study were chromatographic analysis the essential oils, fruit mass reduction effect, total soluble solids, peel color and fruit firmness. Regarding the adjustment and viability of the essential oil concentrations to be used in the treatments, a phytotoxicity test was performed. The main constituent found in Noni essential oil was octanoic acid, while for Lippia essential oil was thymol. The concentration of $3 \%$ of Noni and Lippia essential oils was the maximum to reach an acceptable level of phytotoxicity on papaya fruit peel. The paraffin + L. sidoides and paraffin + M. citrifolia treatments achieved the lowest reduction in pulp mass. In relation to total soluble solids, treatments did not show a significant difference. The best result for firmness was found in sunflower oil + noni coating. Sunflower oil + noni and sunflower oil + octanoic acid were the treatments that maintained normal yellow color in fruits for longer time.
\end{abstract}

Keywords: Carica papaya L.; fruit quality; post-harvest.

Practical Application: Biofilms associated with essential oils reduced the loss of mass, firmness and the color of the fruit for a longer time.

\section{Introduction}

Papaya (Carica papaya L.) is a tropical species belonging to the Caricaceae family, of great worldwide importance. It is grown mainly in tropical countries. Much appreciated by consumers (Santos et al., 2009). Brazil is o the second largest producer of papaya in the world according to the Brazilian Fruit Farming Yearbook of 2017, considered the third largest world's producer of fruit (Food and Agriculture Organization of the United Nations, 2018; Editora Gazeta, 2017). Among the states with the highest production, Bahia and Espirito Santo together account for $64.32 \%$ of Brazilian production (Instituto Brasileiro de Geografia e Estatística, 2017). However, it is known that papaya has a relatively short shelf-life after harvesting, with losses near to $40 \%$, depending on storage conditions. Other factors that occur in pre- and post-harvest conditions can also reduce or accelerate fruit metabolism, resulting in quantitative and qualitative losses in the different commercialization phases (Zamperlini et al., 2007). Tropical fruits typically have high moisture content, easily damaged soft-textured pulp and high respiratory rates. Those characteristics combined with heat-generating packaging, as well as the lack of auxiliary treatments, such as the use of plant regulators that slow down maturation-related processes may represent the rapid senescence of fruits (Chitarra \& Chitarra, 2005; Godoy et al., 2010). According to Brady (1987) and Tucker \& Grierson (1987), degradation and synthesis of pigments, conversion of starch to sugars, reduction in the firmness, degradation of pectins and alteration in enzymatic activity, all occur over maturation processes.

Considering these factors, in the minimally processed products industry, several methods have been used, such as using edible coatings, plastic films or solutions with waxes that can contribute to increase the useful life of fruits, minimally processed, reducing gas exchange, water loss, respiration and oxidation reaction, as well as helping to reduce physiological disorders (Zambolim et al., 2002; Ali et al., 2011; Rojas-Graü et al., 2009). Edible coatings can be prepared from proteins, polysaccharides, lipids or a mixture of these components (Cao et al., 2007). In papaya, gelling agents such as cassava starch, alginate and rice amino have been used as coatings (Pereira et al., 2006; Tapia et al., 2008; Trigo et al., 2012). In addition, it is possible to reconcile edible coatings with preservative agents to prolong their useful life. Among the different groups of plant products, one option found was the use of essential oils, especially because they have antimicrobial properties, antioxidants, antiseptic activity, that is, bactericide, fungicide and virucide, they are used in food preservation (Chevalier et al., 2016). A study has shown that the mixture of cassava starch, glycerol and clove essential oil helps to maintain the quality of papaya (Holsbach et al., 2019).

Among other conservation methods, cold storage has reduced efficiency due to the problems with cold injury (Fagundes et al., 2006) and the use of controlled atmosphere (Vidrih et al., 1990) has a 
very high implantation cost. The inclusion of essential oils (EOs) to different biofilms becomes an alternative in the development of active films in the protection of fruits, also providing antimicrobial and antioxidant action. According to the consulted literature, there is no work trying to associate biofilms to noni and Lippia essential oil with their major constituents (octanoic acid and Timol, respectively) and their effects on the conservation qualities of tropical fruits. In this sense, the use of biofilms associated with essential oils is due to the fact that they represent an interesting possibility for the preservation of food, prolong the shelf life of food and avoid or reduce contamination by microorganisms. Thus, the objective of this work was to evaluate the use of edible coating based on essential oils associated with different biofilms, on the quality and conservation of papaya fruits.

\section{Materials and methods}

\subsection{Essential oil achievement}

Ripe noni (Morinda citrifolia L.) fruits and leaves of alecrim-pimenta (Lippia sidoides Cham.). Were collected in the afternoon in the dry season, in the region of Gurupi, in the state of Tocantins, with coordinates Latitute $11^{\circ} 43^{\prime} 30^{\prime \prime}$ South, longitude $49^{\circ} 4^{\prime} 34^{\prime \prime}$ 'West. The ripe noni fruits were washed and cut into small pieces and the leaves of lippia were dehydrated at room temperature $25 \pm 2{ }^{\circ} \mathrm{C}$ for seven days, after drying they were cut into small pieces. The essential oil was extracted by means of hydrodistillation method in Clevenger apparatus, which consisted of putting $200 \mathrm{~g}$ of the plant material in $500 \mathrm{~mL}$ of water in a 1-L round bottom flask and boiling for two hours. After extraction, the essential oil was collected as a supernatant, stored in an amber-colored flask, identified and kept at $4{ }^{\circ} \mathrm{C}$ until bioassay implantation (Seixas et al., 2012, adapted).

\subsection{Chemical composition of lippia and noni essential oil}

The chemical composition of the essential oils (lippia and noni oil) was determined through gas chromatography mass spectrometry (GC-ME). The chromatograph used in the study was the Shimadzu GC-210 model equipped with a QP2010 Plus selective mass detector. The equipment was operated under the following conditions: RTX-5MS fused silica capillary column (30 $\mathrm{m} \times 0.25 \mathrm{~mm} \times 0.25 \mu \mathrm{m}$ film thickness) with the following column temperature setting: $60-240{ }^{\circ} \mathrm{C}\left(3{ }^{\circ} \mathrm{C} / \mathrm{min}\right)$; injector temperature: $220^{\circ} \mathrm{C}$; helium carrier gas; splitless injection with injected volume of $1 \mu \mathrm{L}$ of a 1:1000 hexane solution. For the mass spectrometer (MS), the following conditions were used: $70 \mathrm{eV}$ impact energy; ion source and interface temperature: $200^{\circ} \mathrm{C}$. A homologous series of n-alkanes (C9H20 ....... C26H54) was injected under the same conditions as the samples. The obtained spectra were compared with the Nist and Wiley 229 library database and the retention index calculated for each constituent was compared with the tabulated one, according to Adams (2007).

The quantification of the compound contents was expressed as a percentage based on area normalization, which were obtained through gas chromatograph equipped with a flame ionization detector (FID), using the Shimadzu GC-210 apparatus, under the following conditions: capillary column RTX-5MS (30 $\mathrm{m} \times 0.25 \mathrm{~mm} \times 0.25 \mu \mathrm{m}$ film thickness); injector temperature: $220^{\circ} \mathrm{C}$; FID temperature: $300^{\circ} \mathrm{C}$; with column programming: initial temperature $60{ }^{\circ} \mathrm{C}$ with a heating rate of $3{ }^{\circ} \mathrm{C} \mathrm{min}-1$ to $240^{\circ} \mathrm{C}$, then moving to a heating rate of $10^{\circ} \mathrm{C} \mathrm{min}-1$ up to $300^{\circ} \mathrm{C}$, remaining at this temperature for $10 \mathrm{~min}$; nitrogen carrier gas $\left(1.18 \mathrm{~mL} \mathrm{m^{-1 }}{ }^{-1}\right.$; Split rate 1:50; $115 \mathrm{kPa}$ column pressure and $1 \mu \mathrm{L}$ injected volume of a 1: 1000 hexane solution.

\subsection{Phytotoxicity in papaya fruits as a function of essential oil concentrations}

Phytotoxicity tests were performed by applying the essential oils of lippia and noni on papaya fruits at the concentrations of $1 ; 2 ; 3 ; 4$ and $5 \%$ and distilled water as a control. Aliquots of essential oil were added in a Tween $80(1 \%)$ solution to obtain the different concentrations. They were spread on the fruit surface with the aid of flexible cotton rods and $200 \mu \mathrm{L}$ of the essential oil solution. After 48 hours, the phytotoxicity was evaluated by means of a grade scale, proposed by Goes et al. (2004), in percentage of damages occurred in the fruit peel, in which: 0 (zero) - fruits with no symptoms of phytotoxicity; 1-fruits with mild symptoms (fruits with slight, barely noticeable tiny spots, with no restriction on the fresh fruit market 1-10\%); 2-fruits with moderate symptoms (fruits with small, visible, localized, sometimes confluent spots, but may be accepted with restriction to the fresh fruit market 11-20\%); 3-fruits with severe symptoms (dark visible spots, occupying variable spaces in the fruit, rejected for fresh fruit market> 20\%).

\subsection{Effect of essential oils associated with different biofilms on weight loss and shelf life of papaya fruits}

Formosa cultivar fruits were used in the tests. They were purchased from the local commerce of Gurupi, Tocantins, produced in orchards of the region. All fruits were uniform in in color and appearance "once and for all", that is, before the maturation phase. They were washed with neutral soap and rinsed in sterile distilled water (ADE). Nine treatments were performed: Control (sterile water), Carnauba Wax (30\%) + L. sidoides (2\%), Gelatin $(30 \%)+$ L. sidoides (2\%), Paraffin $(30 \%)+$ L. sidoides (2\%), Sunflower oil (2\%) + L. sidoides (2\%), Carnauba wax (30\%) + M. citrifolia (2\%), Gelatin (30\%) + M. citrifolia (2\%), Paraffin $(30 \%)+$ M. citrifolia $(2 \%)$ and Sunflower oil $(2 \%)+$ M. citrifolia (2\%). Using $2 \%$ of each essential oil for not causing phytotoxicity. To prepare the coatings, $100 \mathrm{~mL}$ of solution was prepared for each treatment. The solutions were prepared by slowly dissolving the carnauba wax, gelatin and paraffin in distilled water, under stirring and heating, until complete dissolution. When the solution temperature reached $45^{\circ} \mathrm{C}$, essential oil was added, and under stirring, it was subsequently cooled for application to the fruits. The solutions of the treatments were applied to the fruits with the aid of a manual sprayer. Immediately after the treatments, the fruits were placed in plastic trays and stored at a temperature $\left(\mathrm{T}^{\circ} \mathrm{C}\right)$ of $28 \pm 1{ }^{\circ} \mathrm{C}$ and relative humidity (RH\%) ranging from 72 to $85 \%$.

The fruits were weighed on a digital scale (Balmak ${ }^{\circledR}$-ELP 25) to determine the loss of fresh mass during eight days at two-day 
intervals. Three best performing biofilms were selected and noni (M. citrifolia) and lippia (L. sidoides) essential oils and their major compounds, octanoic acid and thymol, respectively, were added. A completely randomized design with three replications in a $3 \times 4+1$ factorial scheme was used, where factor $\mathrm{A}=$ three biofilms and factor $\mathrm{B}=$ two essential oils and two major compounds, and water as the control. The postharvest shelf-life of the fruits was defined by three variables: mass loss (dehydration), the change in peel color and the shelf-life that the fruit presented from the day of installation until it was no longer in good conditions to be marketed and/or consumed (onset of senescence). Mass loss was performed every two days during the test with the aid of a digital scale. Peel color was determined by comparing with the Frutiséries 7 color scale (Brasil, 2000), whose maturity stages range from 0 to 5 , where: 0 ( $100 \%$ green); 1 (up to $15 \%$ of surface is yellow); 2 (up to $25 \%$ of the surface is yellow); 3 (up to $50 \%$ of the surface is yellow); 4 (50\% to $75 \%$ of the surface is yellow), and 5 ( $76 \%$ to $100 \%$ of the surface is yellow). The concentration of total soluble solids ( $\left.{ }^{\circ} \mathrm{Brix}\right)$ was determined in fruit juice using a manual Atago refractometer, with a scale from 0 to $32{ }^{\circ}$ Brix (Carvalho et al., 1990). The firmness of the pulp was determined by making an insertion in the middle of the fruits, with a SoilControl/USA bench penetrometer, model PDBF-200, with an 8-mm tip, expressed in Newton.

Statistical analyzes were performed using the SISVAR software (Ferreira, 2014). Data means related to the fruit characterization and the physical and chemical characteristics were compared using the test of Tukey at 5\% significance level. Storage period data were compared through the Scott Knott cluster test at 5 and $1 \%$.

\section{Results and discussion}

\subsection{Phytotoxicity in papaya fruits as a function of essential oil concentration}

Based on the 3\% concentration, the essential oils caused degree 1 (1-10\%) phytotoxicity as shown in Figure 1. However, at this concentration, the damage to the fruits is minimal, where slight injuries represented by small spots with no restriction on the fresh fruit market. On the other hand, the concentrations of 4 and 5\% were considered unsuitable for use in papaya fruits, as they provided the phytotoxicity grades 2 and 3 respectively, impairing the natural appearance of the fruit peel and therefore, although not affecting the internal pulp of the fruits, the negative visual aspect, makes them unsuitable for commercialization. Other reports of essential oils that caused fruit phytotoxicity have also been reported. Oliveira et al. (2013) used Schinus terebinthifolius essential oil at a concentration level $0.5 \%$ in papayas to test protection against Colletotrichum gloeosporioides. Despite the promising "in vitro response", the oil could not be recommended due to the high levels of fruit phytotoxicity that make it unsuitable for commercialization. Oliveira et al. (2016) also found that Indian clove essential oil causes complete darkening of the peel, possibly due to a phytotoxic activity of this oil.

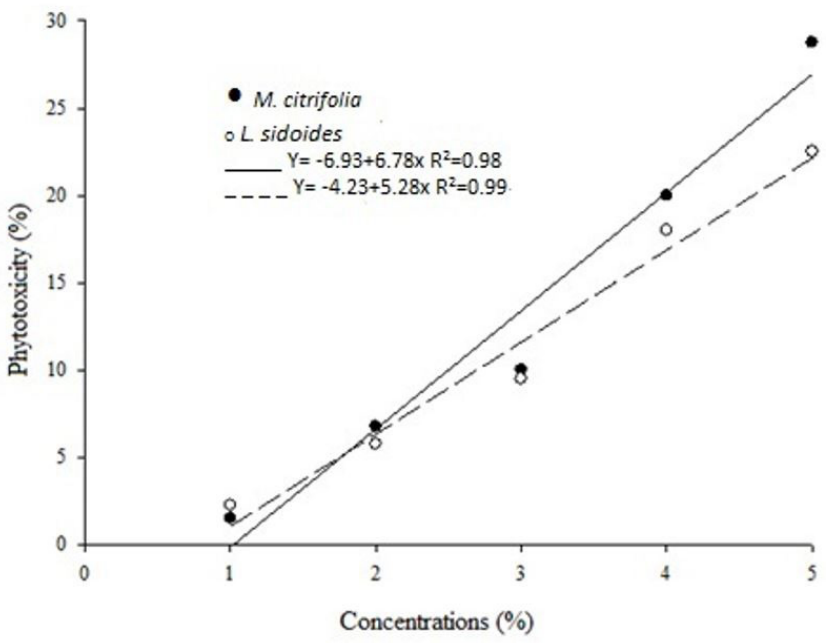

Figure 1. Phytotoxicity of noni (Morinda citrifolia) and lippia (Lippia sidoides) essential oils, due to increasing concentrations applied to papaya fruits.

\subsection{Chemical constituents of lippia and noni essential oils}

The chemical constituents found in lippia and noni essential oils are shown in Table 1. Chromato graphic analyses revealed that thymol was the major constituent $(92,68 \%)$ for lippia essential oil. Regarding noni essential oil, the octanoic acid was its major constituent (82.24\%), followed by hexanoic acid (8.26\%). Similar results to this work have also been obtained by other authors. Veras et al. (2014) and Fontenelle et al. (2007) reported the presence of 84.9 and $59.65 \%$ of thymol, respectively, as a major constituent in essential oils of $L$. sidoides. Different values were reported by Osorio et al. (2018), where they obtained 64.03\% concentration of octanoic acid (caprylic acid) and $8.64 \%$ hexanoic acid (caproic acid) in M. citrifolia essential oil. Pino et al. (2010) identified 96 compounds, of which octanoic acid (70\%) and hexanoic acid (8\%) were the major components. Variation in the content of major oils compounds can be influenced by several factors, such as the degree of fruit ripeness, cultivation conditions and development (soil type and climate) harvest time (Pino et al., 2010; Fontenelle et al., 2007).

\subsection{Dehydration of biofilm-coated fruits incorporated with essential oils}

Over the eight-storage days, a reduction in the fruit mass was observed in all treatments. The results of the mass reduction percentage are shown in Table 2. The fruits treated with paraffin + L. sidoides, paraffin + M. citrifolia and sunflower oil + M. citrifolia presented the lowest mass loss, especially paraffin $+L$. sidoides where the loss was $7.8 \%$ at the end of the storage period (eight days), differing statistically from the control.

Fruits in paraffin + L. sidoides treatment did not differ statistically from the coating with sunflower oil $+M$. citrifolia, during four and six days of storage. Regarding the control treatment, there was the largest mass loss, reaching $23 \%$ of the initial mass in just eight days of storage. Moura et al. (2016), showed that the essential oil at $0.1 \%$ lemon grass allowed a smaller reduction in fruit mass of (4.28\%), probably because 
Table 1. Chemical constituents of lippia (Lippia sidoides) and noni (Morinda citrifolia) extracted from leaves and fruit, identified by GC/ MS and their contents expressed as percentage. Gurupi, Tocantins, 2017.

\begin{tabular}{|c|c|c|c|}
\hline \multicolumn{4}{|c|}{ Lipia sidoides essential oil } \\
\hline Constituents & $\mathrm{RT}(\min )$ & IR & $(\%)$ \\
\hline a-tujeno & 5.915 & 924 & 0.05 \\
\hline a-terpinene & 8.680 & 1014 & 0.09 \\
\hline$\rho$-cimene & 8.944 & 1020 & 1.16 \\
\hline$\gamma$-terpinene & 10.176 & 1054 & 0.25 \\
\hline cis-sabinene hidrate & 10.656 & 1065 & 0.10 \\
\hline 4-terpineol & 15.19 & 1174 & 0.45 \\
\hline Thymol methyl ether & 17.264 & 1232 & 0.43 \\
\hline Thymol & 20.075 & 1289 & 92.68 \\
\hline (E)-caryophylene & 25.369 & 1417 & 2.23 \\
\hline a-humulene & 26.849 & 1452 & 0.13 \\
\hline Caryphylene & 31.878 & 1582 & 0.61 \\
\hline Total & - & - & 98.18 \\
\hline \multicolumn{4}{|c|}{ Morinda citrifolia essential oil } \\
\hline Constituents & $\mathrm{RT}(\min )$ & IR & $(\%)$ \\
\hline 3-methyl-3-butenyl-1-acetate & 4.583 & 888 & $-{ }^{*}$ \\
\hline 2-heptanone & 4.992 & 897 & - \\
\hline Methyl Hexanoate & 5.774 & 922 & - \\
\hline Hexanoic Acid & 7.634 & 987 & 8.26 \\
\hline Ethyl Hexanoate & 7.974 & 999 & 2.48 \\
\hline Methyl Octanoate & 12.713 & 1123 & - \\
\hline Octanoic Acid & 15.603 & 1177 & 82.24 \\
\hline Ethyl Octanoate & 15.803 & 1196 & - \\
\hline Isopentyl hexanoate & 18.537 & 1259 & 1.60 \\
\hline Methyl hexanoate & 19.983 & 1292 & - \\
\hline 3-methylbutyl octanoate & 26.897 & 1457 & 4.25 \\
\hline 3-methylbut-2-enyl octanoate & 28.226 & 1489 & - \\
\hline Total & - & - & 98.77 \\
\hline
\end{tabular}

${ }^{*}$ Not quantified (values $<0.0$ ). RT: retention time; IR: calculated retention index. it restricted transpiration by minimizing the vapor pressure gradient. The application of biofilms generates $\mathrm{CO}_{2}$ accumulation and decrease of $\mathrm{O}_{2}$ available to fruits, thus reducing respiratory rates and ethylene production, which results in delaying the fruit maturation process (Chitarra \& Chitarra, 2005). Fakhouri et al. (2015) found that the use of starch/gelatin-based biofilm (1:1) resulted in the mass loss for grapes was 9\%. Jacomino et al. (2003), when evaluating the effects of five carnauba-based commercial waxes on postharvest preservation of Pedro Sato guavas, found that waxes were effective in retarding ripening, reducing mass loss and rot incidence.

\subsection{Effect of essential oils and their major compounds associated with different biofilms on the quality of papaya fruits}

It can be seen in Table 3 that all treatments had similar total soluble solids (TSS) values, with no significant difference. Carnelossi et al. (2009) found that fruits treated and inoculated 24 hours after treatments did not present significant differences among them for the values of (TSS). Guava (Psidium guajava L.) fruits coated with chitosan + cassava starch or chitosan + cassava starch + mixed essential oils of the genus of Lippia gracilies Schaver showed no significant changes in (TSS) content (Aquino et al., 2015). Perdones et al. (2012) obtained an increase in TSS content in strawberries coated with chitosan and lemon essential oil, however, the values were lower than those obtained for fruits uncoated or coated only with chitosan.

Regarding fruit firmness results (Table 3), a statistical difference was found between treatments. The treatments sunflower oil + octanoic acid and sunflower oil + thymol provided greater firmness of pulp, in which the mixture of sunflower oil and noni essential oil stood out. It is believed that a positive synergism occurred between the fixed sunflower oil associated with noni essential oil as the lipids and oil constituents reduced the metabolism and the permeability of the fruit, therefore reducing the respiratory rate and the delay of ripening.

Cissé et al. (2015) showed that chitosan-coating on mango fruits maintained more initial firmness of the pulp.

Table 2. Water loss in papaya fruits submitted to treatments with different biofilms incorporated to lippia and noni essential oils.

\begin{tabular}{|c|c|c|c|c|}
\hline \multirow{3}{*}{ Treatments } & \multicolumn{4}{|c|}{ Days after application } \\
\hline & 2 & 4 & 6 & 8 \\
\hline & $(\%)$ & $(\%)$ & $(\%)$ & $(\%)$ \\
\hline Carnauba Wax 30\% + L. sidoides $2 \%$ & $4.0 \pm 0.21 \mathrm{ab}$ & $6.1 \pm 0.08 \mathrm{ab}$ & $11.6 \pm 0.04 \mathrm{ab}$ & $19.7 \pm 0.11 \mathrm{ab}$ \\
\hline Gelatin $30 \%+$ L. sidoides $2 \%$ & $4.9 \pm 0.15 \mathrm{a}$ & $7.9 \pm 0.31 \mathrm{a}$ & $11.5 \pm 0.22 \mathrm{ab}$ & $19.5 \pm 0.03 \mathrm{ab}$ \\
\hline Sunflower oil $2 \%+L$. sidoides $2 \%$ & $3.9 \pm 0.26 \mathrm{ab}$ & $5.7 \pm 0.43 \mathrm{ab}$ & $9.7 \pm 0.1 \mathrm{ab}$ & $17.4 \pm 0.19 \mathrm{ab}$ \\
\hline Carnauba Wax $30 \%+$ M. citrifolia $2 \%$ & $3.7 \pm 0.14 \mathrm{ab}$ & $6.0 \pm 0.48 \mathrm{ab}$ & $11.6 \pm 0.02 \mathrm{ab}$ & $20.2 \pm 0.26 \mathrm{ab}$ \\
\hline Gelatin $30 \%+$ M. citrifolia $2 \%$ & $3.6 \pm 0.15 \mathrm{ab}$ & $5.7 \pm 0.49 \mathrm{ab}$ & $9.9 \pm 0.52 \mathrm{ab}$ & $16.6 \pm 0.67 \mathrm{ab}$ \\
\hline Paraffin $30 \%+$ M. citrifolia $2 \%$ & $3.6 \pm 0.15 \mathrm{ab}$ & $5.3 \pm 0.41 \mathrm{ab}$ & $8.8 \pm 0.52 \mathrm{ab}$ & $9.8 \pm 0.51 \mathrm{~cd}$ \\
\hline Sunflower oil $2 \%+$ M. citrifolia $2 \%$ & $3.5 \pm 0.3 \mathrm{ab}$ & $4.1 \pm 0.19 \mathrm{~b}$ & $7.4 \pm 0.21 \mathrm{~b}$ & $14.3 \pm 0.88 \mathrm{bc}$ \\
\hline
\end{tabular}

${ }^{*}$ Means followed by the same letter in the column do not differ statistically from each other by the Tukey test at the $5 \%$ probability level. ( \pm ) standard deviation. 
Table 3. Content of Total Soluble Solids ( ${ }^{\circ}$ Brix) and pulp firmness in papaya fruits under different treatments applied to the skin after 12 days of storage.

\begin{tabular}{lcl}
\hline \multicolumn{1}{c}{ Treatments } & TSS ${ }^{\circ}$ Brix & $\begin{array}{l}\text { Firmness } \\
\text { (Newton) }\end{array}$ \\
\hline Witness & $9.67 \pm 0.02^{\mathrm{ns}}$ & $2.7 \pm 0.15 \mathrm{~b}$ \\
Sunflower oil + M. citrifolia & $8.2 \pm 0.13$ & $7.9 \pm 0.1 \mathrm{a}$ \\
Sunflower oil + L. sidoides & $9.7 \pm 0.19$ & $4.0 \pm 0.25 \mathrm{ab}$ \\
Sunflower oil + O. Ácid & $10.3 \pm 0.34$ & $6.2 \pm 0.45 \mathrm{ab}$ \\
Sunflower oil + Thymol & $9.0 \pm 0.75$ & $6.0 \pm 0.47 \mathrm{ab}$ \\
Gelatin + M. citrifolia & $8.3 \pm 0.31$ & $3.1 \pm 0.50 \mathrm{~b}$ \\
Gelatin + L. sidoides & $9.7 \pm 0.40$ & $5.1 \pm 0.36 \mathrm{ab}$ \\
Gelatin + O. Ácid & $9.3 \pm 0.13$ & $4.1 \pm 0.35 \mathrm{ab}$ \\
Gelatin + Thymol & $9.7 \pm 0.1$ & $4.6 \pm 0.55 \mathrm{ab}$ \\
Paraffin + M. citrifolia & $7.3 \pm 0.3$ & $2.5 \pm 0.15 \mathrm{~b}$ \\
Paraffin + L. sidoides & $8.3 \pm 0.25$ & $3.7 \pm 0.17 \mathrm{~b}$ \\
Paraffin + O. Ácid & $8.7 \pm 0.15$ & $2.7 \pm 0.55 \mathrm{~b}$ \\
Paraffin + Thymol & $8.7 \pm 0.21$ & $5.0 \pm 0.60 \mathrm{ab}$ \\
CV\% & 14.56 & 30.47 \\
\hline
\end{tabular}

Equal lowercase letters in the column do not differ from each other by the Tukey $5 \%$ test. ${ }^{\text {ns }}$ not significant. $( \pm)$ standard deviation. Firmness: Data transformed by square root. C.V $=$ Coefficient of variation

Khaliq et al. (2015) using Arabic gum (GA) 10\% and calcium chloride $3 \%+(\mathrm{AG}) 10 \%$ retained the firmness of fruits for longer. Reduction in respiration and water loss may be responsible for retaining firmness. The use of a suitable coating may delay texture changes and reduce the ripening process as it has been shown by several authors in different fruit varieties (Valero et al., 2013; Maqbool et al., 2011; Ahmed et al., 2009). Weight loss associated with fruit ripening also reflects as a progressive decline in pulp firmness (Forato et al., 2015).

In relation to peel color, sunflower oil associated with noni essential oil and sunflower oil with octanoic acid were the treatments that maintained fruit color and ripeness during the 10-day storage period in which the fruits had not reached full maturity. This result is important for postharvest conservation of fruits, since it was found that from the sixth day, the control was already fully mature, and the fruits were unsuitable for commercialization (Figure 2). It can be verified that the sunflower oil treatments maintained the greenish color of the peel until the sixth day after the treatment. Forato et al. (2015) evaluating cashew gum (CG) and carboxymethylcellulose (CMC) -based coatings both reduced mass loss, preserving firmness and delaying peel color changes in guava fruits. Ripeness of papaya fruits started before harvest, and their ripening progressively increases after harvest, due to physiological processes, which increases transpiration and respiration, thus accelerating their physiological ripening, where the color change is a natural indicator of maturity. During the ripening process, chlorophyll degrades, exposing carotenoids, the main pigment responsible for most of the yellowish shade (Yao et al., 2014).

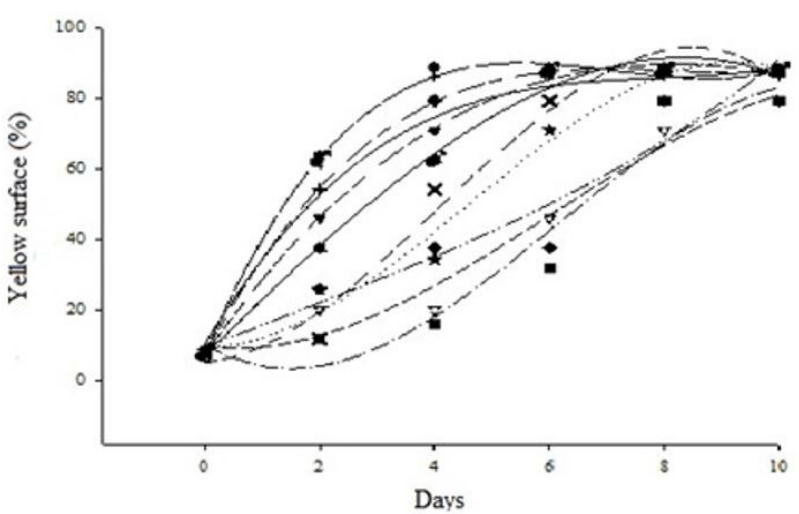

\begin{tabular}{|c|c|c|}
\hline-- & Wintes & $3+16.204 x-0.248 x^{2}-0.0579 x^{3} R^{2}=0.99^{*}$ \\
\hline 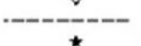 & Sunflower oil $+M$. citrifolid & $y=9.735-2.263 x+2.140 x^{2}-0.1167 x^{3} R^{2}=0.97^{*}$ \\
\hline & Sunflower oil $+L$ sidoides & $y=9.298-0.172+2.835 x^{2}-0.206 x^{3} R^{2}=0.98^{*}$ \\
\hline & Sunflower oil + O. Acid & $y=10.318-9.828 x+3.762 x^{2}-0.205 x^{3} R^{2}=0.93^{n}$ \\
\hline & Sunflower oil + Thymol & $y=9.259+6.566 x-0.150 x^{2}+0.039 x^{3} R^{2}=0.93^{n s}$ \\
\hline & Gelatin $+M$. cit rifolia & $y=7.103+16.203 x-0.248 x^{2}-0.057 x^{3} R^{2}=0.93$. \\
\hline & Gelatin $+L$ sidoides & $y=7.103+16.203 x-0.248 x^{2}-0.057 x^{3} R^{2}=0.93^{*}$ \\
\hline & & $y=5 \cdot 013+1.711 x+3 \cdot 304 x^{2}-0.267 x^{3} R^{2}=0.97^{*}$ \\
\hline & Gelatin + Thymol & $y=7.50+37.798 x-5.580 x^{2}+0.260 x^{3} R^{2}=0.99 *$ \\
\hline & Paraffin $+M$. citrifolia & $y=7.768+30.60 x-3.80 x^{2}+0.154 x^{3} R^{2}=0.99 \bullet \bullet$ \\
\hline-- & Paraffin $+L$. sidoides & $y=7.24+23.40 x-2.025 x^{2}+0.048 x^{3} R^{2}=0.98$, \\
\hline$\Rightarrow$ & Paraffin + 0. Acid & $y=10.28 ; 27.348 x-3.398 x^{2}-0.144 x^{3} R^{2}=0.94^{n s}$ \\
\hline-1 & Paraffin + Thymol & $y=10.28 ; 27.348 x-3.398 x^{2}-0.144 x^{3} R^{2}=0.94^{\text {ns }}$ \\
\hline
\end{tabular}

Figure 2. Ripening of papaya fruits as a function of storage time and different treatments with sunflower and lippia oils associated with different biofilms. ${ }^{\text {ns }}$ ot significant, ${ }^{\star} 5 \%$ and ${ }^{\star *} 1 \%$ probability by Scott-Knott test.

It was observed in this work that the use of essential oil-incorporated biofilm may help maintain the moisture of the fruits, the firmness of the pulp, and delay the ripening of the fruits, thus increasing shelf-life.

\section{Conclusions}

This work proved that the application of oils to the fruit must be less than $3 \%$ due to the phytotoxicity caused by the papaya peel. The coating based on paraffin 30\% + Lippia sidoides $2 \%$ and paraffin $30 \%+$ Morinda citrifolia $2 \%$ on papaya fruits reduces the loss of mass. Sunflower oil $2 \%+$ noni $2 \%$ provides greater mechanical resistance of the fruits (greater firmness). The films composed of sunflower oil + noni and sunflower oil + octanoic acid have been shown to be effective in the formation of coatings that prolong the appearance, reducing the color change of the fruits. These results suggest that the paraffin coatings $30 \%$ with the mixture of essential oils Lippia sidoides and Morinda citrifolia at $2 \%$ are of interest in the use in the form of biofilms of papayas, which are very perishable, and thus extend their useful life at room temperature.

\section{References}

Adams, R. P. (2007). Identification of essential oil components by gas chromatography/mass spectroscopy (4th ed.). Illinois: Allured Publishing Corporation. 
Ahmed, M. J., Singh, Z., \& Khan, A. S. (2009). Postharvest aloe vera gel-coating modulates fruit ripening and quality of 'arctic snow' nectarine kept in ambient and cold storage. International Journal of Food Science \& Technology, 44(5), 1024-1033. http://dx.doi. org/10.1111/j.1365-2621.2008.01873.x.

Ali, A., Muhammad, M. T. M., Sijam, K., \& Siddiqui, Y. (2011). Effect of chitosan coatings on the physicochemical characteristics of Eksotika II papaya (Carica papaya L.) fruit during cold storage. Food Chemistry, 124(2), 620-626. http://dx.doi.org/10.1016/j.foodchem.2010.06.085.

Aquino, A. B., Blank, A. F., \& Santana, L. C. (2015). Impact of edible chitosan-cassava starch coatings enriched with Lippia gracilis Schauer genotype mixtures on the shelf life of guavas (Psidium guajava L.) during storage at room temperature. Food Chemistry, 171, 108-116. http://dx.doi.org/10.1016/j.foodchem.2014.08.077. PMid:25308649.

Brady, C. J. (1987). Amadurecimento de frutas. Revisão anual da Fisiologia das Plantas, 38, 155-178. https://doi.org/10.1146/annurev. pp.38.060187.001103.

Brasil. (2000). Frutiséries: mamão (Boletim Informativo). Brasília: Ministério da Integração Nacional. Retrieved from http://www.integracao.gov.br

Cao, N., Fu, Y., \& He, J. (2007). Preparation and physical properties of soy protein isolate and gelatin composite films. Food Hydrocolloids, 21(7), 1153-1162. http://dx.doi.org/10.1016/j.foodhyd.2006.09.001.

Carnelossi, P. R., Schwan-Estrada, K. R. F., Cruz, M. E. S., Itako, A. T., \& Mesquini, R. M. (2009). Óleos essenciais no controle pós-colheita de Colletotrichum gloeosporioides em mamão. Revista Brasileira de Plantas Medicinais, 11(4), 399-406. http://dx.doi.org/10.1590/ S1516-05722009000400007.

Carvalho, C. R. L., Mantovani, D. M. B., Carvalho, P. R. N., \& Moraes, R. M. M. (1990). Análises químicas de alimentos. Campinas: ITAL.

Chevalier, R. C., Silva, G. F. A., Silva, D. M., Pizato, S., \& Cortez-Vega, W. R. (2016). Edible coating utilization the chitosan base to improve melon shelf life minimally processed. Journal of Bioenergy and Food Science, 3(3), 130-138. http://dx.doi.org/10.18067/jbfs.v3i3.101.

Chitarra, M. I. F., \& Chitarra, A. B. (2005). Pós-colheita de frutas e hortaliças: fisiologia e manuseio. Lavras: Universidade Federal de Lavras.

Cissé, M., Polidori, J., Montet, D., Loiseau, G., \& Ducamp-Collin, M. N. (2015). Preservation of mango quality by using functional chitosanlactoperoxidase systems coatings. Postharvest Biology and Technology, 101, 10-14. http://dx.doi.org/10.1016/j.postharvbio.2014.11.003.

Editora Gazeta. (2017). Brasilian fruit yearbook 2017. Santa Cruz do Sul. Retrieved from http://www.editoragazeta.com.br/sitewp/wpcontent/uploads/2017/03/PDF Fruticultura_2017.pdf

Fagundes, A. F., Dabul, A. N. G., \& Ayub, R. A. (2006). Aminoethoxivinilglicina no controle do amadurecimento de frutos de caqui cv. Fuyu. Revista Brasileira de Fruticultura, 28(1), 73-75. http://dx.doi.org/10.1590/ S0100-29452006000100021.

Fakhouri, F. M., Martelli, S. M., Caon, T., Velasco, J. I., \& Mei, L. H. I. (2015). Edible films and coatings based on starch/gelatin: Film properties and effect of coatings on quality of refrigerated Red Crimson grapes. Postharvest Biology and Technology, 109, 57-64. http://dx.doi.org/10.1016/j.postharvbio.2015.05.015.

Ferreira, D. F. S. (2014). A guide for its bootstrap procedures in multiple comparisons. Ciência e Agrotecnologia, 38(2), 109-112. http://dx.doi. org/10.1590/S1413-70542014000200001.

Fontenelle, R. O. S., Morais, S. M., Brito, E. H. S., Kerntopf, M. R., Brilhante, R. S. N., Cordeiro, R. A., Tomé, A. R., Queiroz, M. G. R., Nascimento, N. R. F., Sidrim, J. J. C., \& Rocha, M. F. G. (2007). Chemical composition, toxicological aspects and antifungal activity of essential oil from Lippia sidoides Cham. The Journal of Antimicrobial Chemotherapy, 59(5), 934-940. http://dx.doi.org/10.1093/jac/dkm066. PMid:17376793.
Food and Agriculture Organization of the United Nations - FAO. (2018). Principais países produtores de papayas. Rome. Retrieved from http://www.fao.org/faostat/en/\#data/QC

Forato, L. A., de Britto, D., de Rizzo, J. S., Gastaldi, T. A., \& Assis, O. B. (2015). Effect of cashew gum-carboxymethylcellulose edible coatings in extending the shelf-life of fresh and cut guavas. Food Packaging and ShelfLife, 5, 68-74. http://dx.doi.org/10.1016/j.fpsl.2015.06.001.

Godoy, A. E., Jacomino, A. P., Cerqueira-Pereira, E. C., Gutierrez, A. S. D., Vieira, C. E. M., \& Forato, L. A. (2010). Injúrias mecânicas e seus efeitos na qualidade de mamões Golden. Revista Brasileira de Fruticultura, 32(3), 682-691. http://dx.doi.org/10.1590/S010029452010005000086.

Goes, A., Martins, R. D., \& Reis, R. F. (2004). Efeito de fungicidas cúpricos, aplicados isoladamente ou em combinação com mancozeb, na expressão de sintomas de fitotoxicidade e controle da ferrugem causada por Puccinia psidii em goiabeira. Revista Brasileira de Fruticultura, 26(2), 237-240. http://dx.doi.org/10.1590/S010029452004000200014.

Holsbach, F. M. S., Pizato, S., Fonteles, N. T., Souza, P. D., Pinedo, R. A., \& Cortez-Vega, W. R. (2019). Evaluation of shelf life of Formosa papaya (Carica papaya L.) minimally processed using coating of cassava starch and essential clove oil. Journal of Bioenergy and Food Science, 6(4), 78-96. http://dx.doi.org/10.18067/jbfs.v6i4.269.

Instituto Brasileiro de Geografia e Estatística - IBGE. (2017). Produção agrícola municipal: tabelas. Retrieved from https://sidra.ibge.gov. $\mathrm{br} /$ pesquisa/pam/tabelas

Jacomino, A. P., Ojeda, R. M., Kluge, R. A., \& Scarpare-Filho, J. A. (2003). Conservação de goiabas tratadas com emulsões de cera de carnaúba. Revista Brasileira de Fruticultura, 25(3), 401-405. http:// dx.doi.org/10.1590/S0100-29452003000300010.

Khaliq, G., Mohamed, M. T. M., Ali, A., Ding, P., \& Ghazali, H. M. (2015). Effect of gum arabic coating combined with calcium chloride on physico-chemical and qualitative properties of mango (Mangifera indica L.) fruit during low temperature storage. Scientia Horticulturae, 190, 187-194. http://dx.doi.org/10.1016/j.scienta.2015.04.020.

Maqbool, M., Ali, A., Alderson, P. G., Zahid, N., \& Siddiqui, Y. (2011). Effect of a novel edible composite coating based on gum arabic and chitosan on biochemical and physiological responses of banana fruits during cold storage. Journal of Agricultural and Food Chemistry, 59(10), 5474-5482. http://dx.doi.org/10.1021/jf200623m. PMid:21476593.

Moura, G. S., Schwan-Estrada, K. R. F., Clemente, E., \& Franzener, G. (2016). Conservação pós-colheita de frutos de maracujá-amarelo por derivados de capim-limão (Cymbopogon citratus). Ambiência, $12,667-682$

Oliveira, E. S., Viana, F. M. P., \& Martins, M. V. V. (2016). Alternativas a fungicidas sintéticos no controle da antracnose da banana. Summa Phytopathologica, 42(4), 340-350. http://dx.doi.org/10.1590/0100$5405 / 2000$.

Oliveira, L. F. G., Jr., Santos, R. B., Reis, F. O., Matsumoto, S. T., Bishop, W. M. S., Machado, L. P., \& Oliveira, L. F. M. (2013). Fungitoxic effect of essential oil from aroeira (Schinus terebinthifolius RADDI) on Colletotrichum gloeosporioides. Braz. J. Med. Plants, 15, 150-157. http://dx.doi.org/10.1590/S1516-05722013000100021.

Osorio, P. R. A., Leão, E. U., Veloso, R. A., Mourão, D. S. C., \& Santos, G. R. D. (2018). Essential oils for alternative teak rust control. Floresta e Ambiente, 25(2), 1-9. http://dx.doi.org/10.1590/2179-8087.039116.

Perdones, A., Sánchez-González, L., Chiralt, A., \& Vargas, M. (2012). Effect of chitosan-lemon essential oil coatings on storage-keeping quality of strawberry. Postharvest Biology and Technology, 70, 32-41. http://dx.doi.org/10.1016/j.postharvbio.2012.04.002. 
Pereira, M. E. C., Silva, A. S. D., Bispo, A. S. D. R., Santos, D. B. D., Santos, S. B. D., \& Santos, V. J. D. (2006). Amadurecimento de mamão formosa com revestimento comestível à base de fécula de mandioca. Ciência e Agrotecnologia, 30(6), 1116-1119. http://dx.doi. org/10.1590/S1413-70542006000600011.

Pino, J. A., Márquez, E., Quijano, C. E., \& Castro, D. (2010). Volatile compounds in noni (Morinda citrifolia L.) at two ripening stages. Food Science and Technology, 30(1), 183-187. http://dx.doi.org/10.1590/ S0101-20612010000100028.

Rojas-Graü, M. A., Soliva-Fortuny, R., \& Martín-Belloso, O. (2009). Edible coatings to incorporate active ingredients to fresh-cut fruits: a review. Trends in Food Science \& Technology, 20(10), 438-447. http://dx.doi.org/10.1016/j.tifs.2009.05.002.

Santos, S. A., Silva, R. F., Pereira, M. G., Alves, E., Machado, J. C., Borém, F. M., Guimarães, R. M., \& Marques, E. R. (2009). Estudos morfo-anatômicos de sementes de dois genótipos de mamão (Carica papaya L.). Revista Brasileira de Sementes, 31(2), 116-122. http:// dx.doi.org/10.1590/S0101-31222009000200013.

Seixas, P. T. L., Castro, H. G., Cardoso, D. P., Chagas, A. F., Jr., \& Nascimento, I. R. (2012). Bioactivity of essential oils on the fungus Didymella bryoniae of the cucumber culture. Applied Research \& Agrotechnology, 5(3), 61-66.

Tapia, M. S., Rojas-Graü, M. A., Carmona, A., Rodríguez, F. J., SolivaFortuny, R., \& Martin-Belloso, O. (2008). Use of alginate-and gellan-based coatings for improving barrier, texture and nutritional properties of fresh-cut papaya. Food Hydrocolloids, 22(8), 1493-1503. http://dx.doi.org/10.1016/j.foodhyd.2007.10.004.

Trigo, J. M., Albertini, S., Spoto, M. H. F., Sarmento, S. B. S., Reyes, A. E. L., \& Sarriés, G. A. (2012). Efeito de revestimentos comestíveis na conservação de mamões minimamente processados. Brazilian Journal of Food Technology, 15(2), 125-133. http://dx.doi.org/10.1590/ S1981-67232012005000005.
Tucker, G. A., \& Grierson, D. (1987). Fruit ripening. In D. Davies (Ed.), The biochemistry of plants (Vol. 12, pp. 265-319). San Diego: Academic Press.

Valero, D., Díaz-Mula, H. M., Zapata, P. J., Guillén, F., Martínez-Romero, D., Castillo, S., \& Serrano, M. (2013). Effects of alginate edible coating on preserving fruit quality in four plum cultivars during postharvest storage. Postharvest Biology and Technology, 77, 1-6. http://dx.doi. org/10.1016/j.postharvbio.2012.10.011.

Veras, H. N. H., Rodrigues, F. F. G., Botelho, M. A., Menezes, I. R. A., Coutinho, H. D. M., \& da Costa, J. G. M. (2014). Antimicrobial effect of Lippia sidoides and thymol on Enterococcus faecalis biofilm of the bacterium isolated from root canals. TheScientificWorldJournal, 2014, 471580. http://dx.doi.org/10.1155/2014/471580. PMid:24683344.

Vidrih, R., Simčič, M., \& Hribar, J. (1990). Storing of persimmon fruit under controlled atmosphere conditions. In Abstracts of the 23th International Horticultural Congress Firenze: ISHS.

Yao, B. N., Tano, K., Konan, H. K., Bédié, G. K., Oulé, M. K., KoffiNevry, R., \& Arul, J. (2014). The role of hydrolases in the loss of firmness and of the changes in sugar content during the post-harvest maturation of Carica papaya L. var solo 8. Journal of Food Science and Technology, 51(11), 3309-3316. http://dx.doi.org/10.1007/ s13197-012-0858-x. PMid:26396325.

Zambolim, L., Costa, H., Ventura, J. A., \& Vale, F. X. R. (2002). Controle de doenças em pós-colheita de frutas tropicais. In L. Zambolim (Ed.), Manejo integrado: fruteiras tropicais: doenças e pragas (pp. 443-512). Viçosa: Universidade Federal de Viçosa.

Zamperlini, I. G. P., Santo, S. K. T., Broetto, S. G., \& Silva, D. M. (2007). Estudos preliminares do comportamento do papaya em diferentes etapas do processo entre a colheita e a mesa do consumidor. In D. S. Martins (Ed.), Papaya Brasil: manejo, qualidade e mercado do mamão. Vitória: Incaper. 